\title{
The Beginnings of Lexicological Concepts in the Age of Enlightenment
}

\section{Introduction}

Several projects were drafted to develop the conceptual frameworks for the dictionaries emerging during the Hungarian linguistic reform and the Reform Era, as well as for the presentation of the Hungarian vocabulary of the time. ${ }^{1}$ An influential plan was submitted to the Marczibányi Competition in 1817 by József Teleki, ${ }^{2}$ who would become the first President of the Hungarian Scholarly Society established in 1830. In 1834, the Society printed for its members the draft of the encyclopaedic dictionary based largely on Teleki's work. Several proposals had been submitted for the 1817 contest, another impactful project coming from Ferenc Verseghy. ${ }^{3}$ After presenting the context, my paper will compare and contrast these two proposals, offering some insights into both contemporary thinking on the subject of the Hungarian and the emerging scientific environment.

\section{Precursors and contemporary conceptions}

György Bessenyei formulated his academic framework in 1781, which included a draft of a dictionary for Hungarian modelled on the dictionary of the French Academy. ${ }^{4}$ His ideas were reflected in Verseghy's encyclopaedic project. In 1790

1 László Gáldi: A magyar szótárirodalom a felvilágosodás korában és a reformkorban [Hungarian Lexicography in the Age of Enlightenment and the Reform Era]. Budapest 1957.

2 József Teleki: Egy tökéletes magyar szótár elrendeltetése, készítése módja [The Function and the Method of Compilation of a Perfect Hungarian Dictionary]. In: Jutalom feleletek a' magyar nyelvről, a Magyar Nemzeti Museum 1815 1816. 1817. esztendei kérdéseire. vol. 2. Pest 1821, pp. 3-69.

3 Ferencz Verseghy: A’ Filozofiának Talpigazságira épített Felelet [A Response Based on the Elemental Truth of Philosophy]. Buda 1818.

4 György Bessenyei: Egy magyar társaság iránt való jámbor szándék [A Benevolent Plan for a Hungarian Society]. Béts 1790. - Note of the editors: For a partial English translation see György Bessenyei: A Benevolent Plan for a Hungarian Society (1781). Translated by Bernard Adams. In: Learned Societies, Freemasonry, Sciences and Literature in 18th-century Hungary:

Acknowledgement: This paper was produced with the support of "Nyugat-magyaroszági irodalom (1770-1820)" Lendület Grant.

https://doi.org/10.1515/9783110637649-013 
Miklós Révai published Bessenyei's work and elaborated his own vision of the linguistic-encyclopaedic conception for the prospective Scholarly Society. ${ }^{5}$ In this programme the unity of grammar and lexicon was already a clearly dominant idea. ${ }^{6}$ It aimed to present the vocabulary as comprehensively as possible, reviving old words or adding dialectal items and neologisms, rather than selecting and normatively regulating usage. Révai's academic plan was printed, but its implementation sadly fell through. Ábrahám Vay would later base the operational principles of the scholarly society on Révai's draft, in which Révai set the development of Hungarian as the main objective of the society, an idea later embraced by István Széchenyi as well. ${ }^{7}$

Révai's conception was promoted by Pál Makó as well, ${ }^{8}$ who saw the dictionary as central to the improvement of the language. Without it, scientific work and poetic expression would be flat and shallow. Albert Szenczi Molnár and Ferenc Pápai Páriz had begun this work, but Makó also highlights the shortcomings of his predecessors: many words in common use were missing, while the various dialectal areas of the country awaited processing. He proposed that older and contemporary authors' works should be included in the corpus, while vernacular and dialectal forms, vocational idioms, and phraseological terms should also be added. He recommended that Hungarian-style derivations be added in order to expand the vocabulary, while in the use of derivatives he subscribed to rigidly consistent and rationalistic principles. He projected a rootbased structure, which was later implemented by Ferenc Kresznerics. He planned to entrust the development of the dictionary to a working group akin to that envisioned by Bessenyei and Verseghy, with headquarters in Pest, coordinated by the Hungarian Society of Pest. József Márton later undertook to realize Makó's concepts with enthusiasm. ${ }^{9}$

A Collection of Documents and Sources. Ed. by Réka Lengyel, Gábor Tüskés, Budapest, MTA BTK Irodalomtudományi Intézet, 2017, pp. 80-89.

5 Miklós Révai: Planum erigendae Eruditae Societatis Hungaricae alterum elaboratius. Viennae 1790. - Note of the editors: For a partial reproduction of the text see Miklós Révai: Planum erigendae Eruditae Societatis Hungaricae alterum elaboratius. In: Learned Societies (note 4), pp. 120-133.

6 László Szelestei N.: Révai Miklós Magyar Tudós Társaság-tervezetének egykorú magyar nyelvü szövege [The Hungarian Contemporaneous Text of the Plan of the Hungarian Scholarly Society Written by Miklós Révai]. In: Magyar Könyvszemle 4 (1998), pp. 397-407.

7 Márta Konczosné Szombathelyi: Tudósportré Révai Miklósról (1750-1807) [A scholarly portrait about Miklós Révai (1750-1807)] In: Modern Filológiai Közlemények 1 (2004), p. 99.

8 Pál Makó: Egy magyar szótárnak készítésére intéző vélemények [Notions about the Compilation of a Hungarian Dictionary] Buda 1792.

9 Gáldi (note 1), p. 129. 
Since its foundation in 1793 the Hungarian Language Society of Transylvania had considered producing a Hungarian dictionary. ${ }^{10}$ Apart from building on existing lexicons, they set out to collect lexical items independently as well. They too cherished the unity of grammar and vocabulary, but they considered the dictionary section more urgent. They believed that while grammars were available here and there, no practical and good dictionary was to be found. Albert Szenczi Molnár's and Ferenc Pápai Páriz’s dictionaries could only be used for the study of Latin. They also established three categories among dictionaries: bilingual (Hungarian and a foreign language), monolingual (Hungarian only), and thesaurus. Their project was modelled on Johann Christoph Adelung's work. ${ }^{11}$ They planned a fully comprehensive dictionary including dialectal variants, phraseologies, old words, neologisms, foreign words, scientific and profession-related vocabulary, proper nouns, vernacular and rustic expressions, and rare words with explanations.

György Aranka encouraged Sámuel Gyarmathi to acquaint himself with lexicographic innovations on his second international study tour. In 1798 the Hungarian Language Society commissioned scholars to formulate what a "good dictionary" should be like. ${ }^{12}$ Gyarmathi drafted his proposal in Göttingen. ${ }^{13} \mathrm{He}$ began with an inventory of contemporary manuscript works (then considered state-of-the-art) from which a Hungarian-Latin dictionary could be compiled, complemented with specialized and vernacular words. He envisioned phraseological collection from foreign-language corpuses, on the basis of foreignlanguage dictionaries. It is important to note that he set out from the linguistic skills of contemporary speakers: he trusted their natural sense for language more than a yet unevolved literary language. The same idea would later return in Verseghy's Felelet (Reply). ${ }^{14}$ Teleki, in contrast, proposed to incorporate the written texts of literary authors without any selective filter. Gyarmathi, presumably upon French and Italian prototypes, recommended that experts and scholars should revise, edit, and proofread the vocabularies of specialist areas. His ordering principles were modelled on the first dictionary of the Academy of Saint Petersburg. He suggested a root-based structure, similar to that projected

10 József Perényi: Aranka nyelvmüvelő társaságának fennmaradt nyelvtudományi kéziratai [Linguistic Manuscripts of the Society of Aranka] In: Magyar Nyelv 6 (1917), p. 189.

11 Perényi (note 10), p. 191.

12 József Perényi: Aranka György magyar nyelvü társasága [The Hungarian Society of György Aranka]. In: Irodalomtörténeti Közlemények I (1918), pp. 14-59.

13 Béla Székely: Gyarmathi Sámuel szótártervezete [The Layout of the Dictionary of Sámuel Gyarmathi]. In: Magyar Nyelv 7-8 (1934), pp. 236-238.

14 Gáldi (note 1), p. 345. 
in Verseghy's Proludium. In keeping with European trends, however, the second edition of the Russian academic dictionary opted for alphabetical ordering instead, and Verseghy's preference in Felelet reflected this too. Gyarmathi tried to establish some order in the somewhat underdeveloped system of alphabetization, which issue Verseghy also touched on in his Felelet. He considered it important to add the origins of loan-words to main entries, specifying the original language, while also marking the words of the Hungarian core vocabulary. It is clear that he was aware of the relative minority of Finno-Ugric root words in Hungarian as opposed to words of foreign origin. He made a point of specifying the relevant part of speech in Latin. His dictionary conception is a thorough and realistic project. Along with it, he proposed a "Hungarian Dictionary to be completed with ease": he suggested that Scheller's German dictionary should be translated, which would later become an important source for Hungarian dictionary literature. ${ }^{15}$ Unfortunately, the end result was not printed in his day, but its effect was felt regardless. The initiative was continued by József Teleki in preparing the dictionaries of the Hungarian Scholarly Society.

The clear direction of contemporary initiatives to cultivate as well as regulate Hungarian can be defined as a unified goal independent of individual strivings, but the various means by which this was to be achieved diverged significantly. Following the example of Adelung, Antal Böjthy proposed a carefully selected vocabulary and unified grammatical rules. He considered the introduction of a uniform and normative approach as central to the purposes of the emerging scholarly society, having obligatory force in linguistic regulation. ${ }^{16}$

In 1793 Verseghy, one of Révai's nominees for membership of the projected scholarly society, ${ }^{17}$ issued his Proludium, ${ }^{18}$ in which he declared his concept of the subsequent academic dictionary. The importance of lexicography is stressed here: although words signify concepts, the expansion of science, culture, and art is only possible through the cultivation of language. Verseghy cited Condillac and Herder addressing the relation between language and thinking. Grammar and dictionary are tightly synthesized here as well. His draft relies on several pillars. First, it is a normative, explanatory dictionary that would process words

15 Gáldi (note 1), p. 142.

16 Tivadar Thienemann: Német és magyar nyelvújító törekvések [Efforts for Neologisms in German and Hungarian]. In: Egyetemes Philológiai Közlemények II (1912), pp. 78-138.

17 Gáldi (note 1), p. 131.

18 Franciscus Versegi: Proludium in institutiones linguae hungaricae [...]. Pestini 1793. 
based on Adelung's model, complete with a grammatical apparatus. It aims to define root words. This is what he called etymology; this type of dictionary would ultimately be created by József Kassai and Ferenc Kresznerics, but root-hunting also featured in the fragment of the dictionary that the Hungarian Language Society of Transylvania projected. The next pillar is the plan for twelve special dictionaries, from which the universal dictionary of Hungarian, a "lexicon universale" may evolve, combining everyday words with specialist vocabularies. We may find a Western antecedent for this tripartite lexicographical unit: Gottfried Wilhelm Leibniz had also envisioned a threefold dictionary. ${ }^{19}$ Verseghy formulated the plan of the academic encyclopaedic dictionary, the implementation of which he wanted to entrust to the projected Scholarly Society. He commenced sketching out the first instalment, to which purpose he devoted much of his time even during the period of his captivity. His later draft in Felelet (1818) transcended this conception: he was projecting a word-investigating dictionary paying due care to fixed phrasal expressions. The threefold nature of dictionary composition was manifest here, too, though he abandoned the idea of root-based organization and adopted the European trend of alphabetical ordering without word batches. Hungarian dictionary writing had by then caught up with the development of European lexicography.

But the early nineteenth century raised some more pessimistic plans as well. In his letter to Ferenc Kazinczy, ${ }^{20}$ József Dessewffy claimed that publishing a new Hungarian dictionary would be a respectable mission for a scholarly society, but it was impossible under the circumstances prevailing in Hungary. Dessewffy expressed macabre views regarding the state of education, book publishing, and censorship.

All contemporary initiatives, independently of each other, clearly targeted the improvement as well as the regulation of Hungarian. The paths to the implementation of these targets, however, led in divergent directions. In each project, distinct problems had to be solved, such as the material, task, and purpose of the dictionary, its normativity, the issues of archaisms, neologisms, foreign words, the attitude to grammar, as well as the methodology and questions of science management.

19 Gáldi (note 1), p. 532.

20 Kazinczy Ferencz összes müvei [The Complete Works of Ferencz Kazinczy] Ed. János Váczy. vol. V. Budapest 1894, pp. 425-428. 


\section{A Comparison of Ferenc Verseghy's and József Teleki’s Dictionary Drafts}

The Marczibányi Competition of 1817 formulated three questions. How can one make a perfect dictionary? Should it incorporate archaic language and dialectal words? How could this be most optimally be implemented? Of the responses, I shall now contrast future President of the Hungarian Scholarly Society József Teleki's realist approach and the project submitted by Verseghy, who had a rationalistic attitude to language. ${ }^{21}$

Teleki's draft ${ }^{22}$ begins with a panoramic view of Hungarian and European achievements, providing a realistic snapshot of the contemporary state of Hungarian. He lists the Hungarian and foreign-language dictionaries of the preceding period, mentioning the works of Gábor Pesti, Albert Molnár, Ferenc Pápai Páriz, and József Márton, which serve to facilitate the learning of Latin and German. In addition, he refers to foreign models, primarily to the Crusca dictionary and the French Academy, but also to the work of Dutch, Spanish, English, and Russian language societies and Polish and German dictionary initiatives. Though he refuses the rigidity of the French Academy, he projects an advisory and instructive dictionary which aims at normativity on the one hand, and a responsible commitment to language planning and native language erudition on the other, such as the normalization and unification of unclear orthographies, where a dictionary might help distinguish correct and incorrect forms. Another important function is to acquaint foreigners with Hungarian, and even the Hungarians themselves, since the description of their mother tongue is sporadic and inadequate. The aims of a dictionary comprise the processing of the meaning of Hungarian words as well as a presentation of their usage, mode, nature, etymology, and prehistory. A dictionary is considered fundamental for the improvement of our language and the creation of high-quality scholarly works. Grammars are not sufficient for this purpose since they address language at large rather than individual words. This is how great dictionaries are created, incorporating all the words of a language. The task of a dictionary is to describe our vocabulary, with its shortcomings as well as values. Writers might also thus be helped in avoiding the use of wrong or mistaken words. Until such a Hungarian dictionary is available it is impossible to cultivate the language too; nor will high-quality scientific and artistic writings be produced. Every cultured nation has now faced this necessity. Teleki mentions those precursors who recognized this lack and worked for the creation of a dictionary and started

21 Gáldi (note 1), pp. 342-350.

22 Teleki (note 2). 
collecting words: György Kalmár, Mátyás Ráth, Sándor Balog, József Frabritz, Ferenc Verseghy. József Kassai had prepared his Hungarian dictionary along the guidelines provided by Adelung. The dictionary should provide orientations in the following areas: what words belong to our language, what are their grammatical properties, interpretations, etymologies, derivative potentials. Verseghy plans a dictionary to trace and link words. Of the words of science, only the most necessary should be added, after which special dictionaries of various sciences and crafts could be created. Taken all together, they would encompass a full encyclopaedia. While Teleki does not address this issue, Verseghy stresses that the dictionary should pay attention to the linking together of words, that is, fixed expressions and collocations. Both find it important to explore the structure and derivation of words. Their attitude differs in the definition of tracing: Teleki, just like Gyarmathi, is aware of the difference between root and derived words, and in the etymological section he would even account for the different foreign language forms of loan-words. Verseghy, in contrast, remains within the system of Hungarian root words.

Their concepts of an encyclopaedic dictionary also diverged. Teleki had in mind a single, large-scale work, a great dictionary, whereas Verseghy suggested a "lexicon etymologico-syntacticum", a set of specialized dictionaries, and the complete encyclopaedia in the Proludium. Teleki's dictionary is practically what Verseghy envisioned in the third phase of his enterprise.

What should be the content and structure of the dictionary? Teleki suggests including the vocabulary of Hungarian literary authors (Pázmány, Gyöngyösi, Zrínyi, Faludi, Virág, Kisfaludy, Csokonai, Berzsenyi) and colloquial words. He labels categories as new, obsolete, and dialectal. He argues for the inclusion of suffixed forms and derivatives. Although this aspect does not feature in the Crusca dictionary or the works of the French Academy and D'Alembert, Adelung's processing can be adapted to Hungarian, insofar as the marking of suffixing and derivation becomes central. He sets up a multi-perspective set of criteria for adding new words, in which authors and forms dictated by fixed idiomatic terms play a dominant role. In the case of new words, he suggests that the variants used by literary authors be adopted, as in the case of new words used by the scientific community, whether they are formulated "correctly" or "incorrectly". Thus, fixed forms following common usage overwrite grammatical classification. He promotes the consultation of available manuscripts as well as of new words introduced by contemporary authors. Among foreign words, their widespread domestic use is crucial. Alluding to Leibniz, he claims that Hungarian scientific language does not yet have the standard to complete specialist dictionaries for individual sciences and professions; terminology is far too meagre as well. In terms of grammatical markers, he relies on the systems of Adelung and D'Alembert. 
Verseghy $^{23}$ assumes a diametrically opposite position, denying the use of the systematic processing of the language of writers. He considers the words in older works of literature obsolete, while saying that new books are full of wrong usage. He has a devastating view of contemporary language usage because of confusing word formations and many foreign loan-words. He claims that the Hungarian Crusca dictionary would not be able to set a standard if it reflected these conditions. He doubts and refuses the idea of harvesting literary works for a vocabulary corpus. Like Gyarmathi, he also champions the Hungarianization of bilingual dictionaries, notably German-Latin ones. The linguistic lore of literary works should not serve as a source to be processed but as a source of fertile inspiration. He intends only to add the most necessary words, while the collection of specialist vocabulary should be delegated to individual special dictionaries developed later. The collection of phraseologies carries particular importance with him. He does not stress the normative role of a dictionary as much as Teleki, but he does touch on it in the realm of grammar. He lays particular emphasis on the architecture of grammar, syntax, and lexicon. The scholarly society intent on creating a dictionary should first prepare its grammar and syntax, and then proceed to the lexicon proper.

Teleki believes that the usage of literary authors and fixed idiomatic usage should be decisive in matters of obsolete or vernacular words. When it comes to old words, he considers Révai's works instructive. He points to the significant gaps in the collection of dialectal words, dismissing Gyarmathi's corpus as unsubstantial. Verseghy deems it important to admit old words and their explanations, but solely for contemporary interpretations, clearly marked as such.

Teleki allows for Hungarian, as well as Latin and German explanations, following the guidelines of the Crusca, but he approves the models of the French Academy, Dr Johnson, and Adelung in aiming to spread correct Hungarian usage with the help of his dictionary. The influence of D'Alembert and the Crusca can be seen in the issue of the dictionary authors' tasks: they need not establish the meaning of every single word in philosophical terms but should direct readers' attention towards subtle differences between meanings of words. He also touches on the difference between synonyms. He discusses the nature of homonymy and proposes that homonyms should constitute separate entries. He argues for the inclusion of proverbs and parables. Teleki differentiates between literal and figurative meanings, too, which was a significant achievement in the period. Verseghy proposes to interpret every word and expression in Latin and German; the former because of the traditions of erudition, the latter because of its European

23 Verseghy (note 3). 
culture. He warns against Hungarian explanations because the chaotic state of an emerging language might result in ever-growing obscurity.

In organizing and managing the dictionary work and science in general, Teleki gives a realistic assessment of contemporary Hungary. Since scientific discourse is in its infancy he does not see a chance to publish a continuously improved dictionary printed in subsequent corrected editions. He would model the workgroup for the dictionary enterprise on other European scholarly societies. By nature, a dictionary is a collective enterprise. He mentions the Crusca dictionary community as well as the scholarly societies in France, Spain, and Russia. All Hungarian scientists should be involved in the creation of the dictionary since the domestic status of science does not allow any one scholar to dedicate his entire life to this single project. There is no scholarly society that could be entrusted with the tasks of such an undertaking. He encourages all patriots to participate, considering them data providers. With regard to tiresome work demanding much field research, he proposes incentives, extended to those collectors who contribute dialectal words, lesser-known expressions, or antiquated words and phrases gleaned and defined from older authors. The editors should be appointed by a society respected by the entire nation. He envisions the creative work to unfold under the aegis of the projected scholarly society; the dictionary should be finalized by three scholars assisted by an advisory board. Emerging problems should be submitted to the society, which would have the right to resolve them. He refers to the French Academy, among whose primary tasks was the preparation of a dictionary. He expects that wealthier inhabitants of Hungary to sponsor the undertaking.

Verseghy was more cautious and sceptical. He proposed that an editor-inchief and ten colleagues coming from different regions should do the bulk of the work, while some associates might help collect lexical items in the counties. The participants should inspect each other's work, with final decisions made by the editor-in-chief. Verseghy, too, was rather modest in terms of financing and royalties. Still in the absence of a Scholarly Society, he considered the National Museum as a potential institutional centre of dictionary writing, but the editorial board that he recommended foreshadowed what would later become the Dictionary Committee of the Hungarian Academy of Sciences.

\section{Summary}

Certain principal questions in the above projects remain open to the present day. Verseghy was the more linguistically educated scholar of the two, but also more rigid and rationalistic. Despite being a literary author, he was 
baffled by Hungarian literature. Teleki presented a richer and more thorough set of Hungarian and international references. He canonized his contemporaries, so to speak: Csokonai, Kisfaludy, and Berzsenyi. He aimed accurately to set down the principles of how and what to collect. Verseghy, on the other hand, took a lexicographer's stance in relation to the problems he faced. Teleki was also the one who considered the compilation of proper nouns. Modelled on foreign dictionaries, he proposed adding the names of persons to historical dictionaries, while listing Hungarian Christian names as linguistic specialties in a separate appendix called a compendium. He would follow the same principles in the case of geographic names. Teleki was realistic in avoiding the criterion of completeness and focusing on a systematic collection of linguistic data. The weakness of his plan was the intention to lay down theoretical guidelines. Verseghy was more practical and particular. A truly progressive conception might have resulted from the filtering together of both projects.

Surveying Teleki's and Verseghy's vision of a Hungarian dictionary and comparing them with the projects of the last decade of the eighteenth century, we see persistent progress, a clarification and crystallization of ideas, which would subsequently lead to the dictionary projects of the Hungarian Scholarly Society and, eventually, to the dictionaries of the Academy. ${ }^{24}$

24 Gáldi (note 1), p. 350. 